\title{
FORT NAMUTONI: FROM MILITARY STRONGHOLD TO TOURIST CAMP
}

\section{Col Dr Jan Ploeger*}

“... this fortress was not just a white elephant, it was actually occupied and played a major role in the settlement of Germans in the far North." (own translation) - D.W. Krynauw Die Verhaal van Namutoni, p 3.

\section{Introduction}

Fort Namutoni, the last White outpost east of the familiar Etosha Pan, has seen a long and varied history. Namutoni was initially referred to as a swampy fountain covered with reeds. This was in the year 1851 when the first White travellers Francis Galton (1822-1911) and Charles Andersson $(1828-1867)$ reached this part of South-West Africa on their way to Ondangua.

At later dates travellers, like the missionaries Carl Hugo Hahn (1818-1895) and Johannes Rath, as well as the English merchant Frederick Green (1829-1876), passed this swamp on their way to Ovamboland.

In 1886 the botanist Hans Schinz (1858-1924) appeared in the same vicinity of Amutoni or Namutoni. Some Transvaal trek-farmers also ar- rived in this area which was proclaimed a prohibited area in 1897 by the German rulers in German South-West Africa because of the then current rinderpest. A series of German posts were built from Otjituo to Namutoni, adjacent to the Etosha Pan and up to Okuokuejo and Tswasis. The purpose of this imaginary line of more than $500 \mathrm{~km}$ was to keep the feared disease from spreading to German occupied part of German South-West Africa. Namutoni lay on the road from Otavi to Ondangua.

After the disappearance of rinderpesi this border post remained as a place from which an eye could be kept on the smuggling (weapons, alcohol, ammunition) going on between the German territory and Ovamboland. The occupation force, consisting of an NCO, a health officer and a couple of horsemen, was provided with reed huts for living quarters.

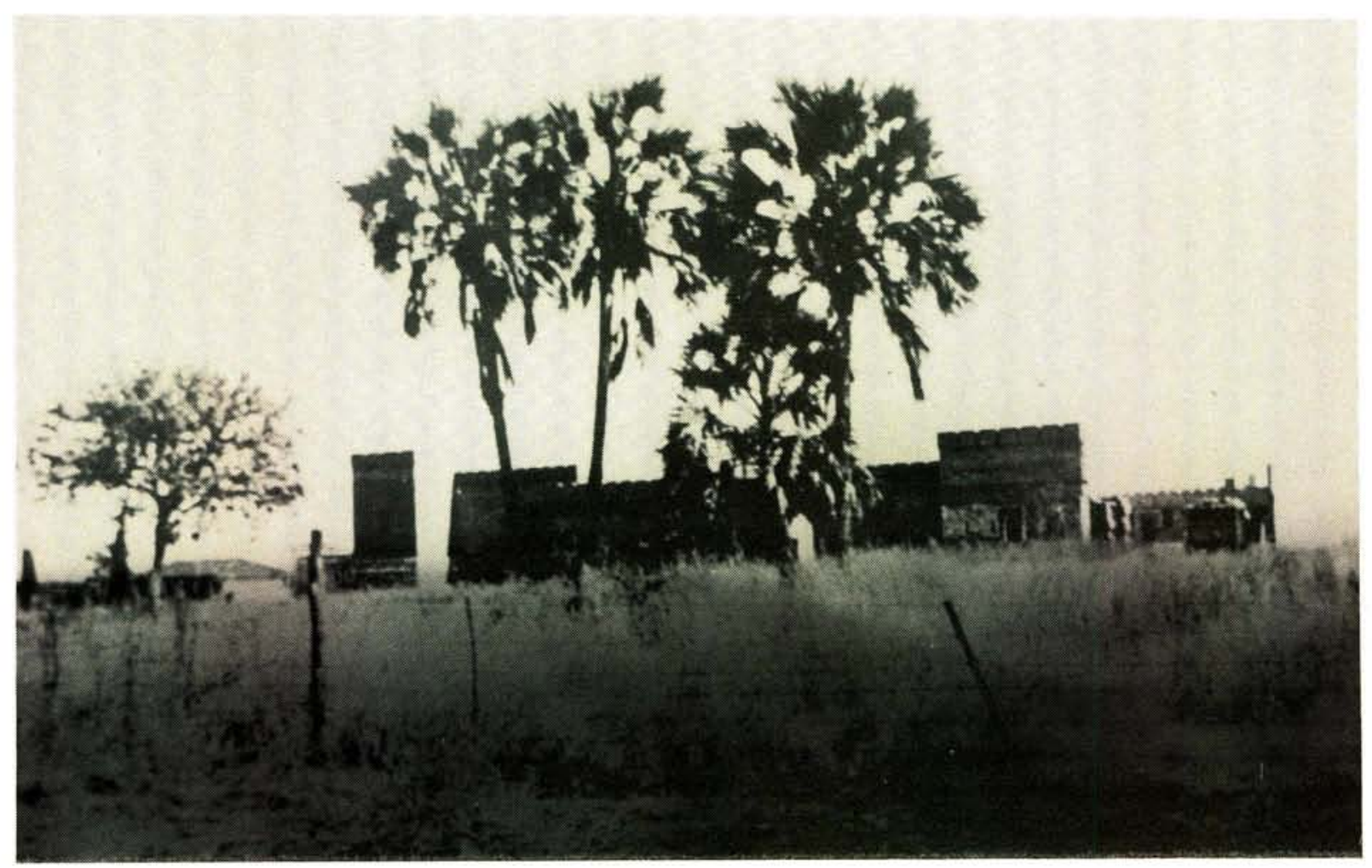

Fort Namutoni during a period of neglect prior to its final restoration. Photo: State Archives, Windhoek. 


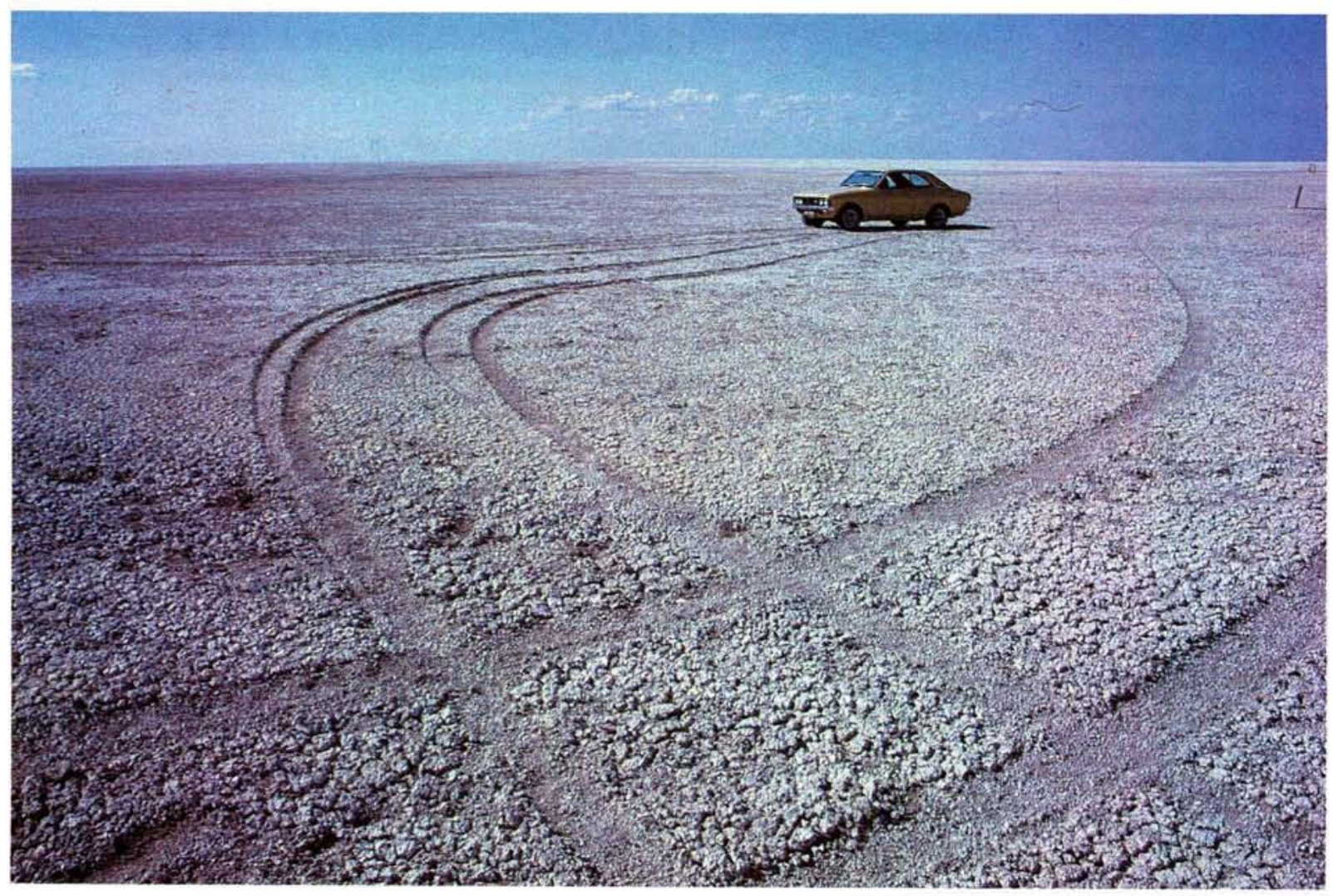

During dry periods the Etosha Pan, within the Etosha National Park is a sea of patterned dry mud.

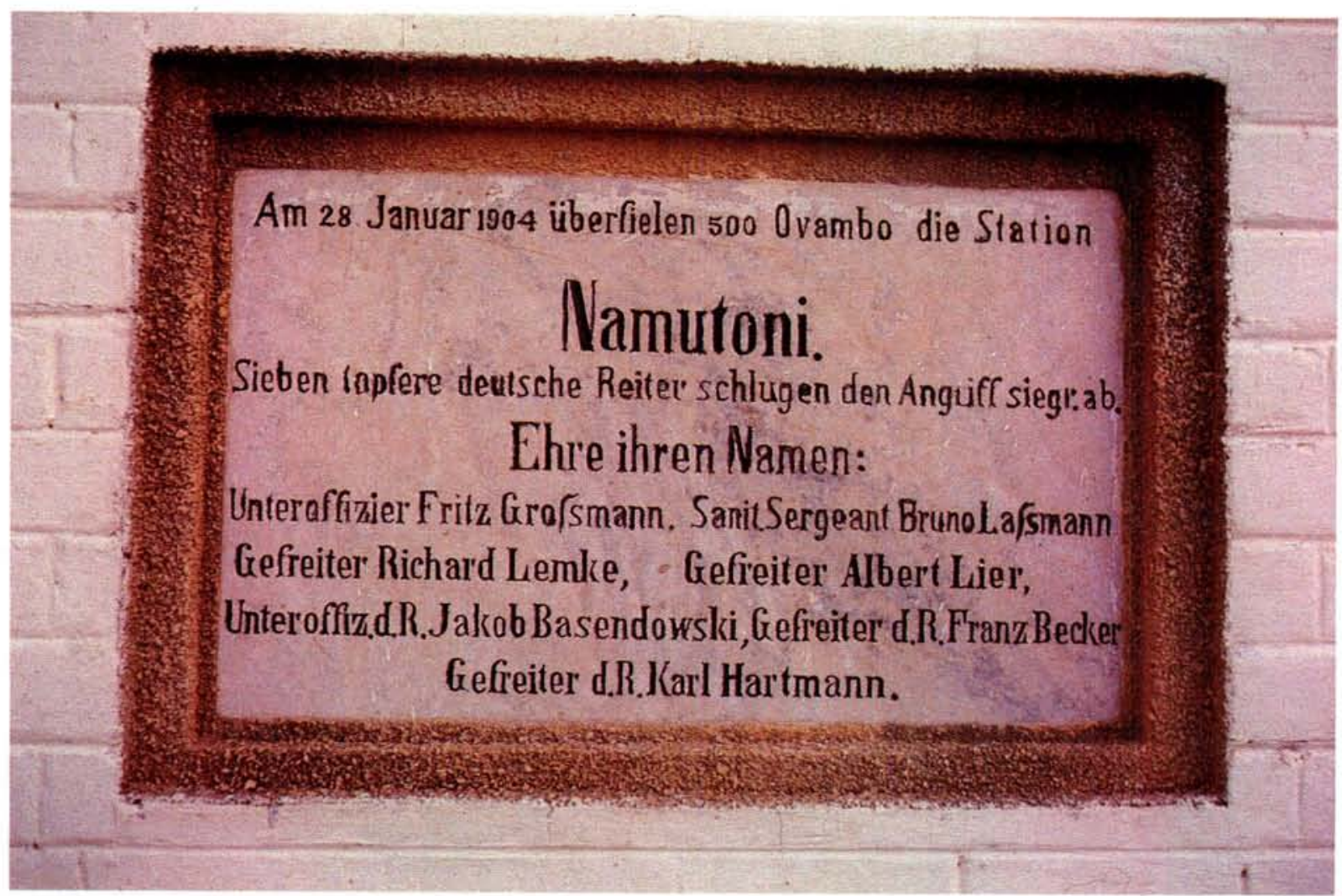

A plaque set in the wall (can be seen on the right hand side of the rear cover photo: inset) in honour of the seven defenders of Fort Namutoni in 1904. 


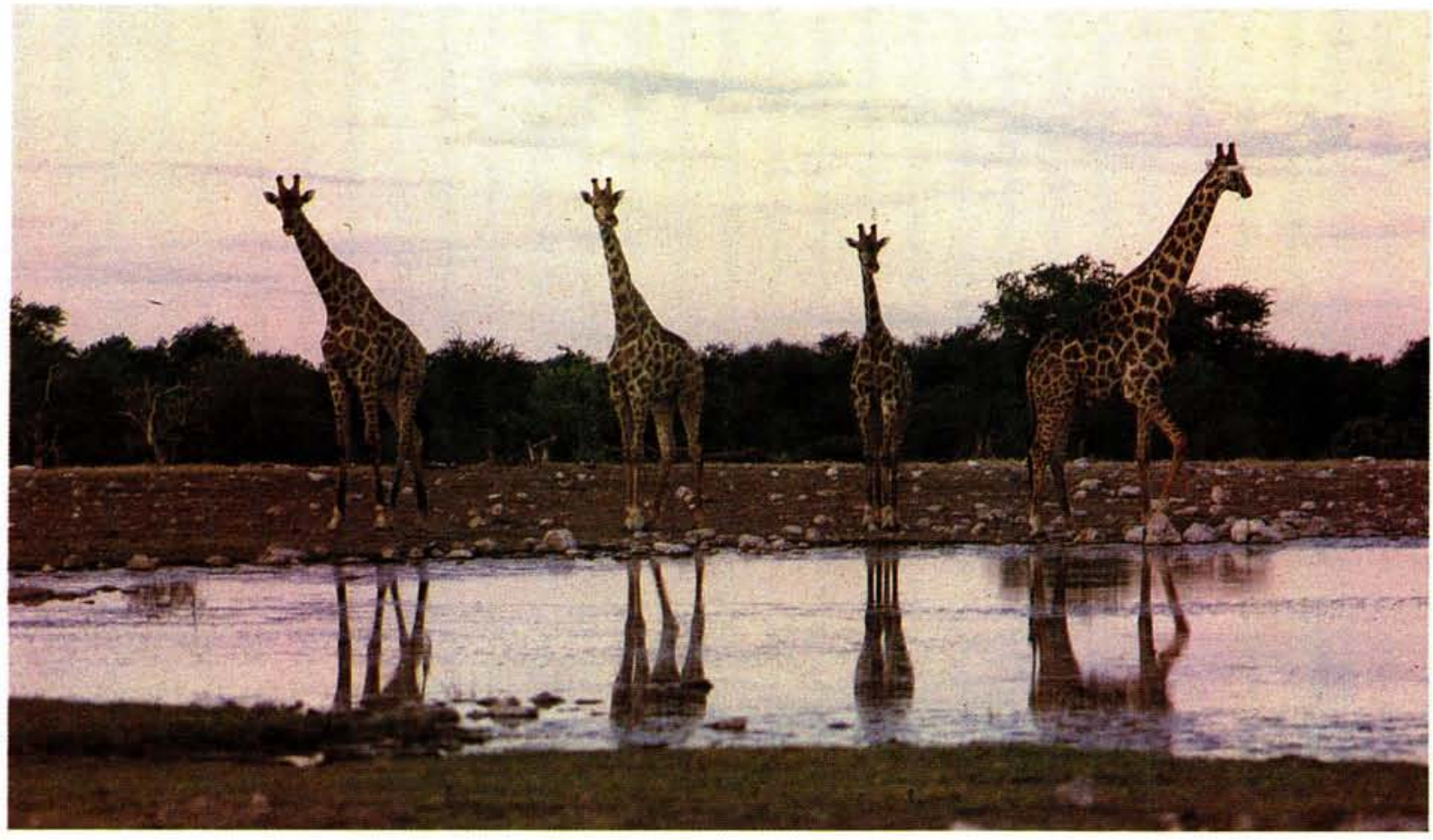

Wild animals and bird life at a waterhole near the Fort.

All colour photographs relating to Fort Namutoni and the Etosha National Park were taken by Eric McPherson, editor of Militaria, during a visit in June 1974.

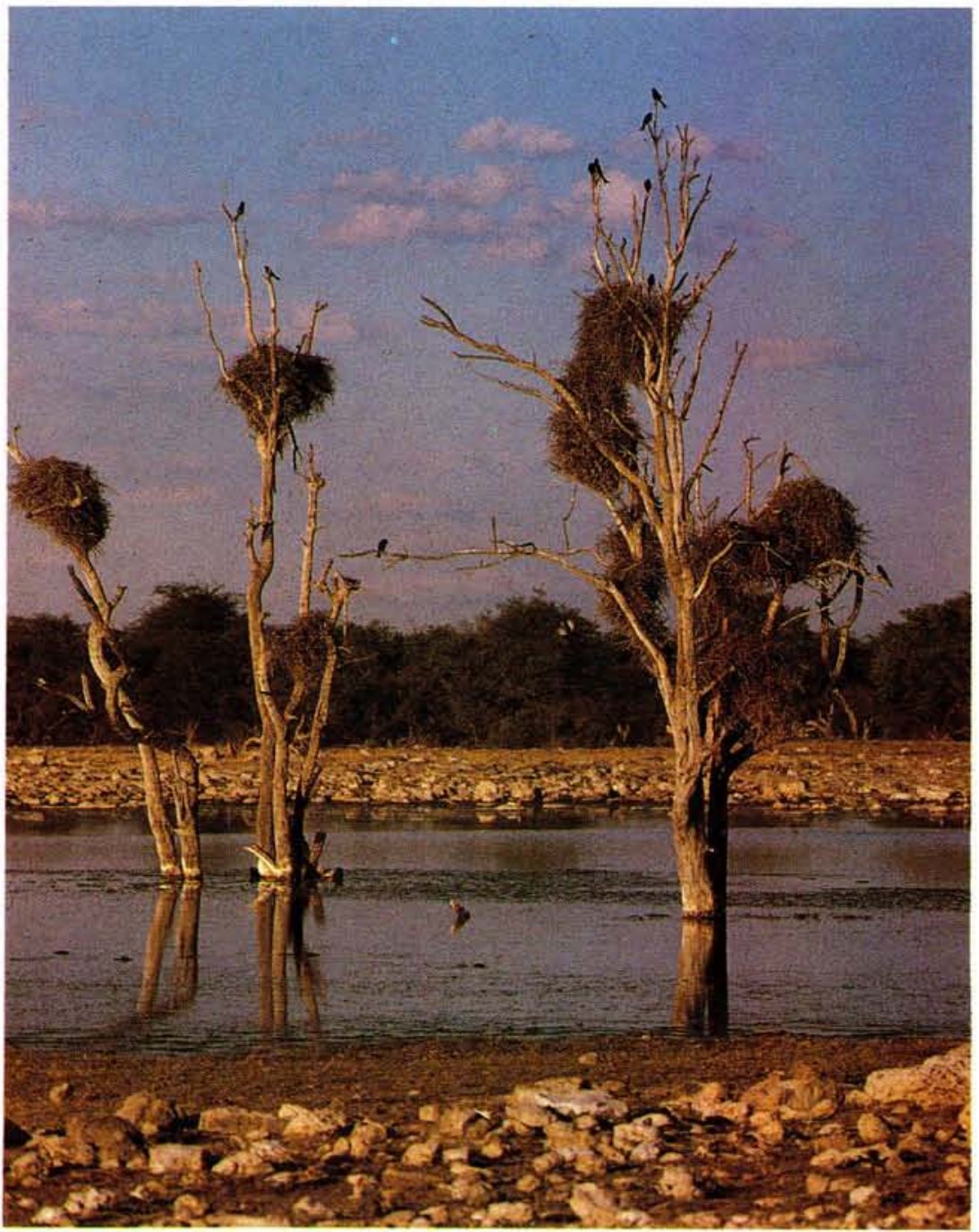




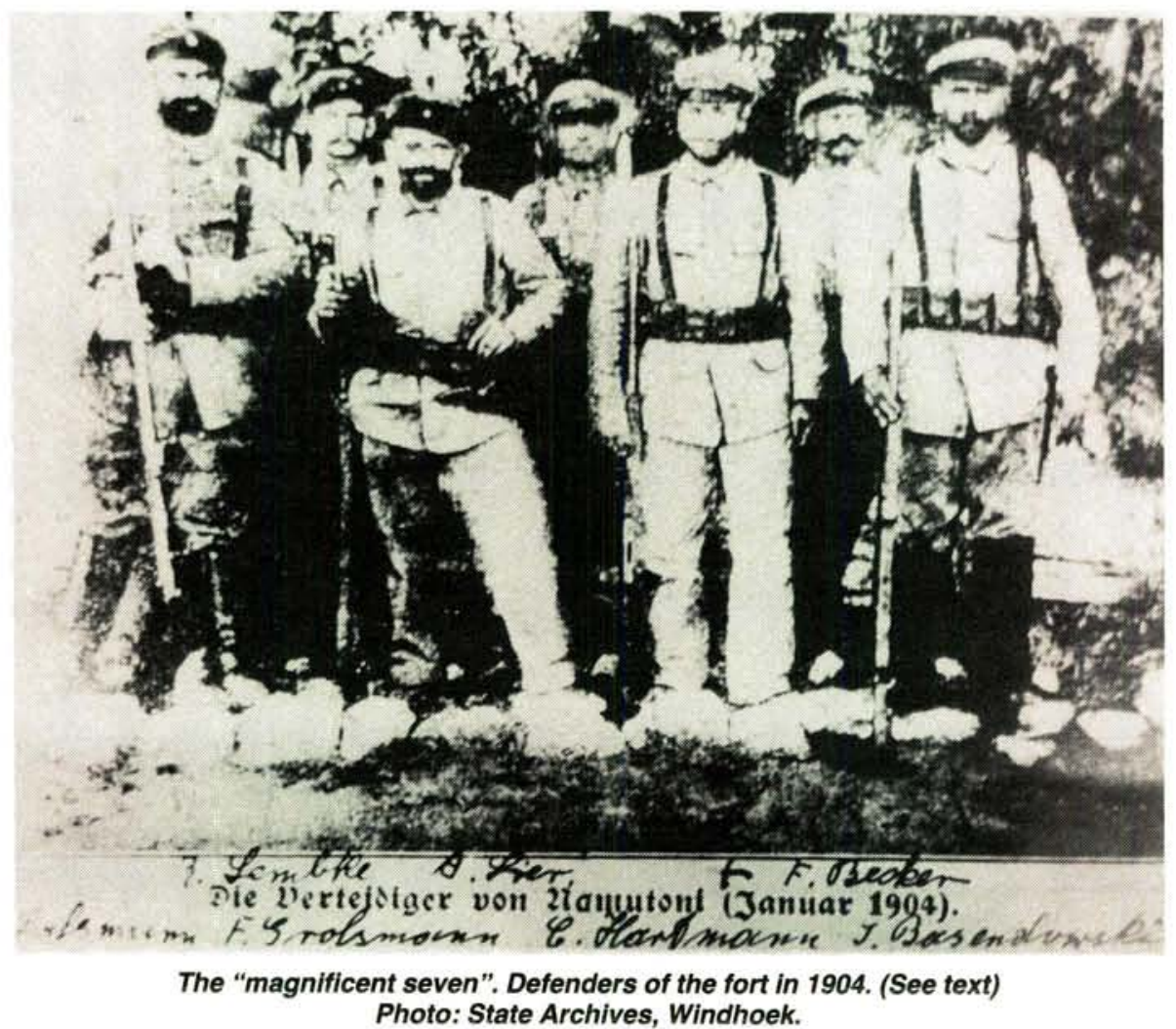

Plans for replacing these huts with a fortified building were propagated by the district head for Grootfontein, Lt R. Volkmann, chief surgeon, Dr Paul Jodtka (1889-1902), and the forest officer, Dr Gerber, during and before 1902.

\section{The building}

Dr Jodtka was given the task of having the first "fort" Namutoni built. The building measured $8 \mathrm{~m}$ by $24 \mathrm{~m}$ with six rooms for the military occupants. It also had a kitchen, a harness-room and four porches. Unburnt bricks and galvanised iron were used as building material. The battlements and loopholes gave it a fort-like appearance.

The incidents during January 1904 proved that the precautionary defence measures were not based on flights of fancy.

On 11 January 1904 unrest among the Hereros led to a rebellion against the German colonial regime. The rebels received the support of Chief Nehale of Ovamboland who launched an attack against Fort Namutoni with 500 Ovambos. On 28 January 1904, the day of the attack, the complement of German soldiers in the fort was as follows: NCOs Fritz Grossman and Jakob Base- ndowski, Health Sergeant Bruno Lassmann and Soldiers 1st Class Richard Lemke, Albert Lier, Franz Becker and Karl Hartmann. The occupants of the fort were subjected to continuous attacks by 500 Ovambos until these eased and eventually stopped late in the afternoon. According to some sources the attackers suffered seventy to eighty casualties, while other sources estimate the number at around 200. Before the attack, the defenders had 1500 rounds of ammunition which was reduced to 150 rounds when counted after the attack. They considered it prudent to vacate the strong-hold and disappear into the bush.

During the night and the next morning the Ovambos were confronted with an empty fort, but they did obtain a big prize in the form of cattle. After this the plundered Namutoni remained temporarily unoccupied...

\section{The Second Fort Namutoni}

The remains of the first fort were reached late in 1904 by a group of German soldiers under Lt Wossidlow. A new fort, in the form of an irregular square of $60 \mathrm{~m}$ by $68 \mathrm{~m}$ and with four towers, was started under the command of Lt Wossidlow and one of his followers Lt Count von Sauma- 


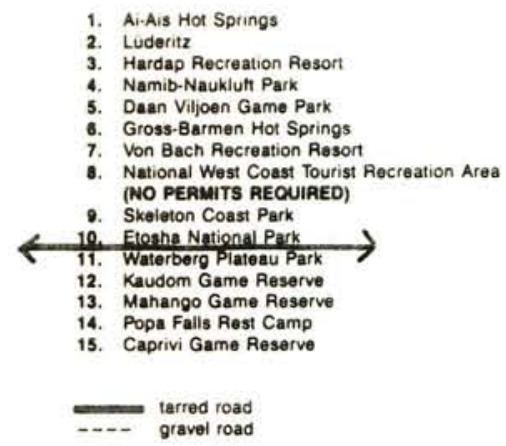

Jeltsch, with the assistance of other members of the occupation force. Count von Sauma-Jeltsch saw the fort completed with rooms for officers and other ranks, a bakery, a store-room and similar amenities. This military building is considered the most attractive of its kind in German South-West Africa and its main purpose was to stop smuggling to Ovamboland and to monitor incoming Ovambo labourers.

When the disturbances in the interior and the rebellions in parts of German South-West Africa came to an end, the military purpose of the strong-hold ceased. The military occupation of the fort ended in 1910 and was replaced by a few policemen but was eventually closed in 1912.

The fort was occupied by Union (South African) troops shortly before the German military surrender at Khorab (1915).

The deserted fort slowly but surely fell into decay and cries went up for its demolition...

\section{Recovery - A New Destination}

The South-West African Monument Commission was founded in 1947. It was suggested that the ruined Fort Namutoni be declared a historical monument and to proceed with restoration. This decision followed in 1950. It was also decided to develop a camp for tourists who would be housed in the restored building. Funds for the restoration were made available in 1951 by the Executive Committee for South-West Africa. Five years later the original builder's drawing of $\mathrm{Na}$ mutoni was found in the archives in Windhoek and the rebuilt strong-hold was opened to tourists in 1957.

The official opening followed, with the transference of the building to the Parks Board, on 28 June 1958.

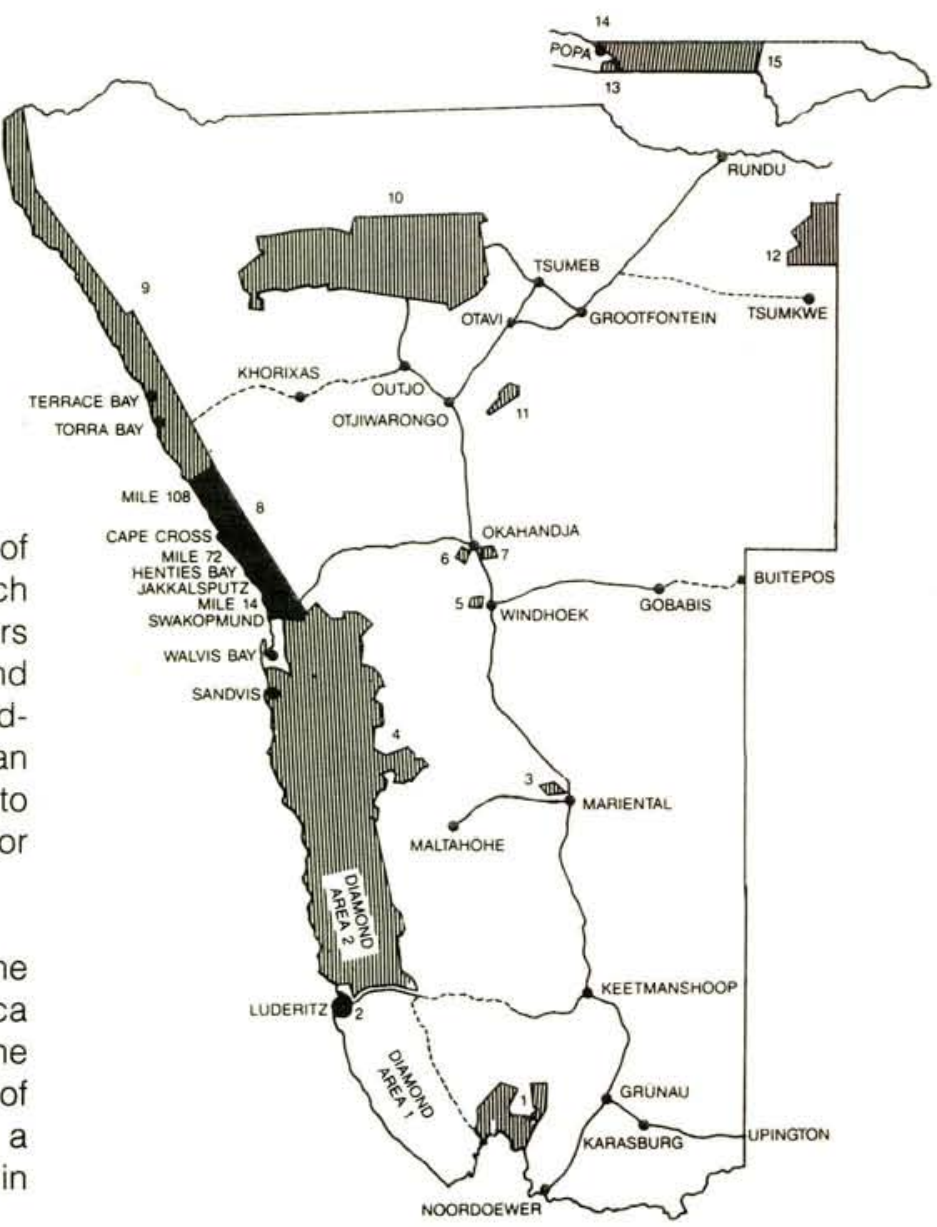

Map of SWA/Namibia. Fort Namutoni is situated within the Etosha National Park; indicated as No. 10 on the map.

A new destination was thus created for the former "defender" of the old German colonial settlement area of South-West Africa and forms a precious part of the monumental heritage of Southern Africa.

* Col Dr Jan Ploeger (Retired)

\section{Bibliography:}

COLLYER, J.J. 1939. Die Veldtog in Duits Suidwes-Afrika 1914-1915. Pretoria.

KRYNAUW, D.W. 1964. Die Verhaal van Namutoni. Windhoek.

MOSSOLOW, N. 1971. Die Verhaal van/Die Geschichte von/The History of Namutoni. Windhoek.

BRUWER, J.P. van S. 1966. South-West Africa: The Disputed Land. Cape Town.

VEDDER, H. ? Einführung in die Geschichte Südwestafrikas. Windhuk.

Persons interested in visiting Fort Namutoni may write to:

The Director

Directorate National

Conservation and Recreational Resorts

Booking Office

Private Bag 13267

WINDHOEK

9000 


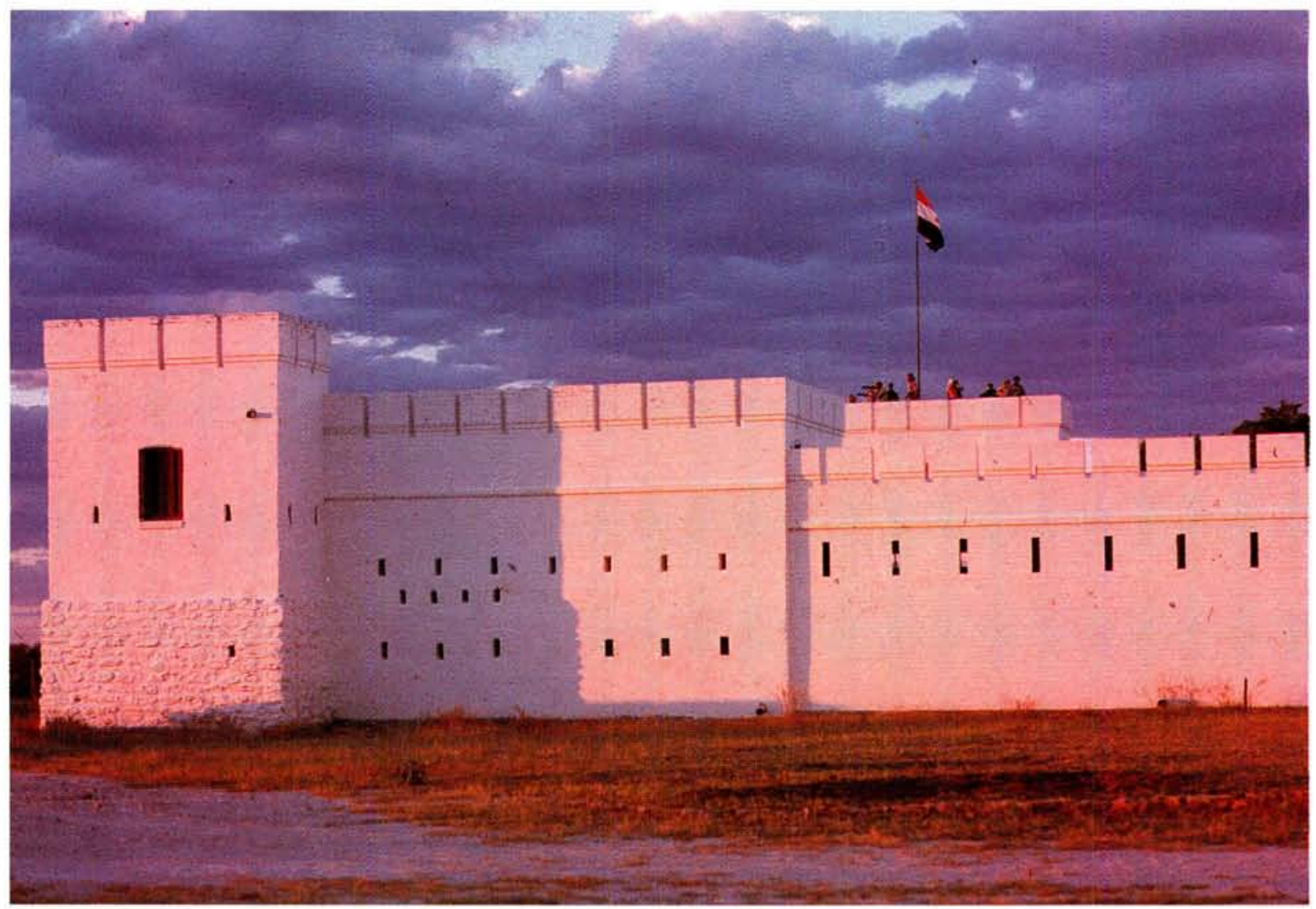

Dawn at Fort Namutoni

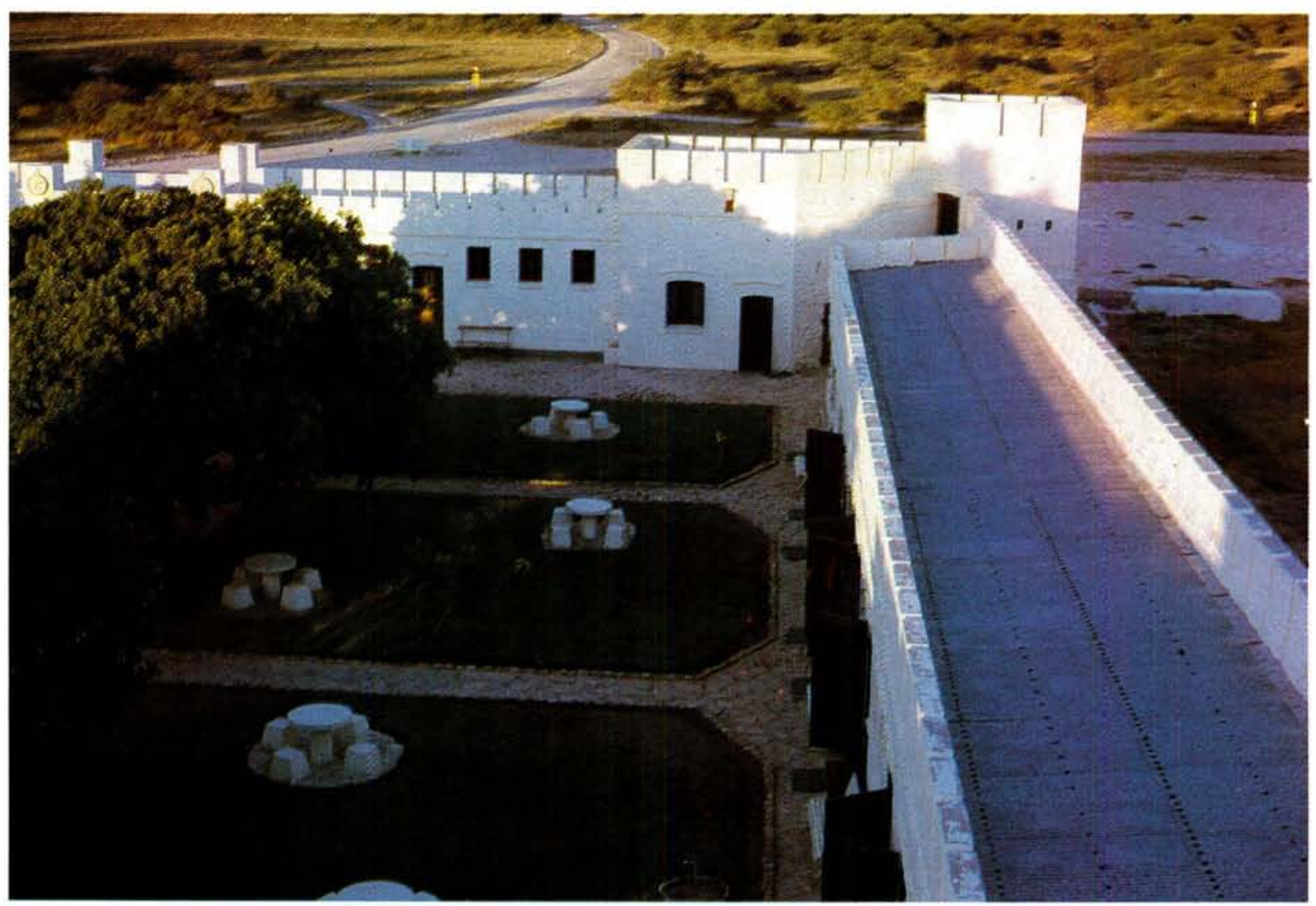

View from the tower onto the courtyard. Accommodation is available both within and outside Fort Namutoni. 


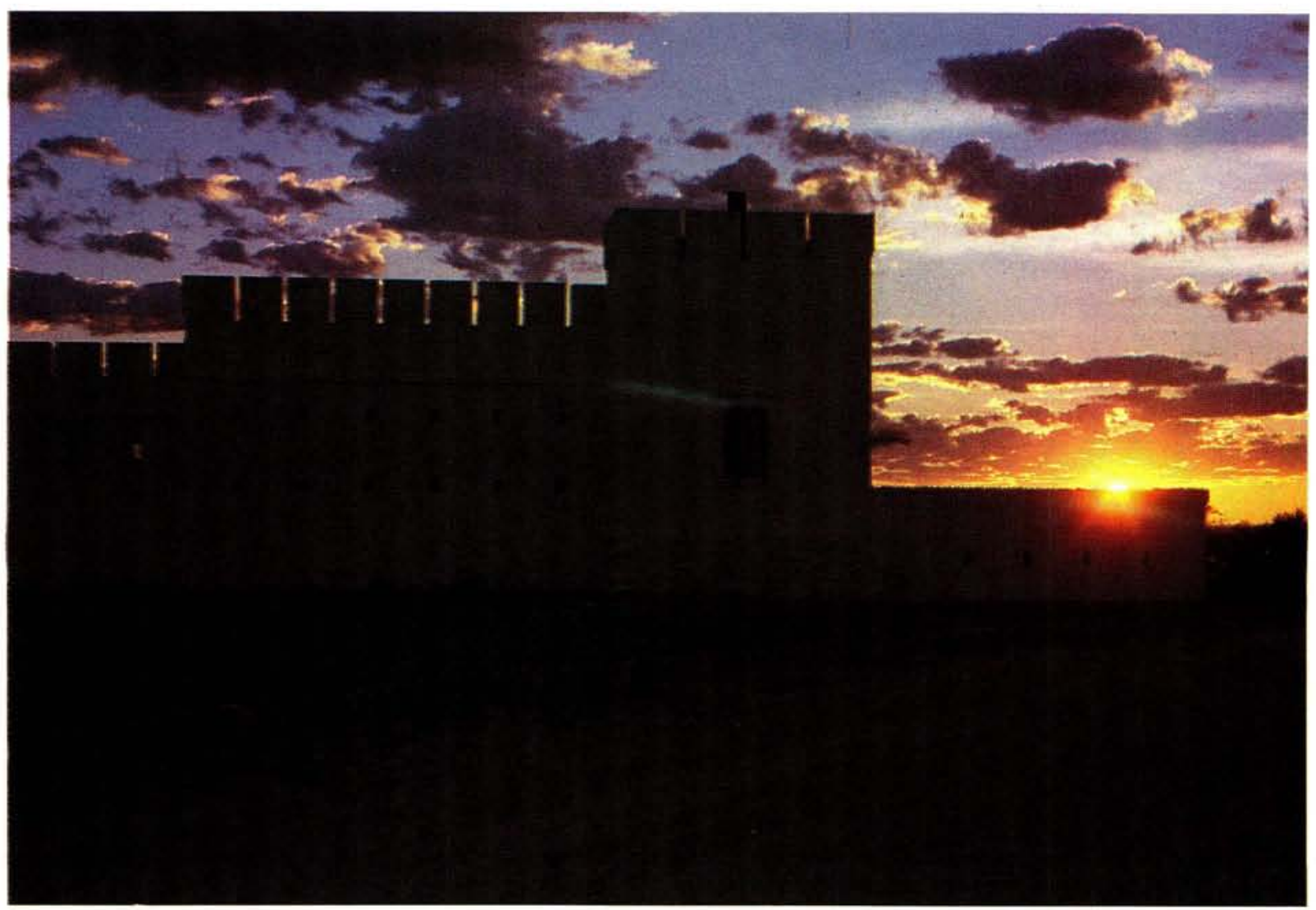

